\title{
Monoclonal Antibody 96.5 F(ab)
}

National Cancer Institute

\section{Source}

National Cancer Institute. Monoclonal Antibody 96.5 F(ab). NCI Thesaurus. Code C29206.

A monovalent Fab fragment of the mouse monoclonal antibody (MoAb) 96.5, raised against an epitope from human melanoma-associated cell surface marker p97. MoAb 96.5 Fab fragments are composed of one constant and one variable domain of each of the heavy and the light chain which together shape the antigen binding site at the amino terminal end of the monomer. MoAb 96.5 Fab fragments are obtained through papain digestion in the presence of cysteine. The advantage of using MoAb 96.5 Fab fragments over whole antibodies is that they have reduced immunogenicity, better penetration of tissues, rapid clearance from the body and that they do not induce precipitation. 